\title{
PENGARUH JARAK TANAM DAN PEMBERIAN PUPUK ORGANIK CAIR DI GROW TERHADAP PERTUMBUHAN DAN HASIL TANAMAN BAWANG DAYAK (Eleutherine americana Merr)
}

\section{The Effect of Planting Distance and Provision of DI Grow Liquid Organic Fertilizer on the Growth and Yields of Dayak Onion Plant (Eleutherine americana merr)}

\author{
T. Rosmawaty, Zulkifli, Mardani \\ Program Studi Agroteknologi Fakultas Pertanian UIR, J1. Kaharudin Nasution No. 133 Perhentian Marpoyan \\ Pekanbaru 28284 Riau, Telp 0761-72126 ext 123, Fax; 0761-674834. \\ Email: T.Rosmawaty@agr.uir.ac.id / Ir.Zulkifli-ms@gmail.com \\ [Diterima: Maret 2019; Disetujui: April 2019]
}

\begin{abstract}
Dayak onion has many benefits, namely anti-inflammatory, stopping the bleeding, anti-breast cancer, heart disease prevention, immunostimulant, anti-tumor, high blood pressure-lowering drugs (hypertension), and diabetes. Dayak onion bulbs contain flavonoids, saponins, polyphenols, alkaloids, glycosides, steroids, phenolics, tannins, triterpenoids, and quinones. DI Grow liquid organic fertilizer is the latest generation of organic fertilizer in agriculture. This fertilizer contains nutrients at a balanced level and also plant growth regulators such as auxin, gibberellin, and cytokinin. This research aims to find out the interaction and the main effect of planting distance and DI Grow liquid organic fertilizer to the growth and the yield of Dayak onion. The research was carried out in the Experimental farm of the Faculty of Agriculture, Islamic University of Riau, Pekanbaru. This research was carried out during 7 months, starting from April to November 2018. The experimental design is a Completely Randomized Factorial Design. The observed parameters are the relative growth rate, net assimilation rate, the number of clump tubers, clump wet weight, and clump dry weight. The results showed that the interaction between planting distance and DI Grow fertilizer did not significantly affect on all the observed parameters. The main effect of planting distance and DI Grow fertilizer was found on all parameters with the best treatment at a planting distance of 25x30 (J4) and DI Grow fertilizer dose of $9 \mathrm{ml} / \mathrm{L}$ of water (D3).
\end{abstract}

Keywords: Dayak onion, Planting distance, DI Grow fertilizer

\begin{abstract}
ABSTRAK
Tanaman bawang dayak memiliki banyak manfaat yaitu sebagai anti radang, menghentikan pendarahan, anti kanker payudara, mencegah panyakit jantung, immunostimulant, anti tumor, obat penurun darah tinggi (Hipertensi), penyakit kencing manis. Umbi bawang dayak mengandung senyawa flavonoid, saponin, polifenol, alkaloid, glikosida, steroid, fenolik, tanin, triterpenoid dan kuinon. Pupuk organik cair DI Grow adalah pupuk organik generasi mutakhir yang dikenal di dunia pertanian. Pupuk ini mengandung unsur hara dalam kadar yang seimbang dan juga mengandung zat pengatur tumbuh tanaman berupa auksin, giberelin dan sitokinin. Tujuan penelitian untuk mengetahui pengaruh interaksi dan utama dari jarak tanam serta Pupuk Organik Cair DI Grow terhadap pertumbuhan dan hasil tanaman bawang dayak. Penelitian ini telah dilaksanakan di Kebun Percobaan Fakultas Pertanian Universitas Islam Riau, Pekanbaru. Penelitian ini telah dilaksanakan selama 7 bulan yang dimulai dari bulan April sampai dengan November 2018. Rancangan percobaan yang digunakan adalah RAL Faktorial. Parameter yang diamati adalah laju pertumbuhan relatif, laju asimilasi bersih, jumlah umbi perumpun, berat basah perumpun dan berat kering perrumpun. Hasil penelitian menunjukkan bahwa secara Interaksi jarak tanam dan pupuk DI Grow tidak berpengaruh nyata terhadap semua parameter yang diamati. Namun Pengaruh utama jarak tanam dan pupuk DI Grow nyata terhadap semua parameter dengan Perlakuan terbaik pada jarak tanam 25 x 30 (J4) serta pupuk DI Grow dosis pupuk $9 \mathrm{ml} / \mathrm{l}$ air (D3).
\end{abstract}

Kata kunci : Bawang dayak, jarak tanam, DI Grow 


\section{PENDAHULUAN}

Bawang Dayak merupakan tanaman khas Kalimantan Tengah yang secara turun temurun di pergunakan masyarakat suku Dayak sebagai tanaman obat. Bawang dayak memiliki banyak manfaat antara lain sebagai anti radang, menghentikan pendarahan, anti kanker payudara, mencegah panyakit jantung, immunostimulant, anti tumor, obat penurun darah tinggi (Hipertensi) dan penyakit kencing manis (diabetes melitus), menurunkan kolesterol, obat bisul, kanker usus dan mencegah stroke (Alves dkk, 2003).

Kandungan umbi bawang dayak terdiri dari senyawa flavonoid, saponin, polifenol, alkaloid, glikosida, steroid, fenolik, tanin, triterpenoid dan kuinon (Sulastri, dkk., 2015). Kemampuan flavonoid sebagai anti oksidan telah banyak diteliti belakangan ini (Sulastri,dkk., 2015; Pratiwi, dkk., 2013; Febrinda, dkk., 2013; Kuntorini, dkk., 2010). Kandungan flavonoid inilah yang dapat mengoptimalkan pemanfaatan tanaman tersebut.

Umbi Bawang Dayak merupakan tanaman khas Kalimantan Tengah yang sudah secara turun temurun di pergunakan masyarakat suku Dayak sebagai tanaman obat. Di Indonesia bawang dayak juga biasa disebut bawang hutan karena selama ini banyak tumbuh liar di hutan Kalimantan, tanaman ini memiliki umbi yang berwarna merah menyala dengan permukaan yang sangat licin. Tanaman bawang dayak memiliki banyak manfaat yaitu sebagai anti radang, menghentikan pendarahan, anti kanker payudara, mencegah panyakit jantung, immunostimulant, anti tumor, obat penurun darah tinggi (Hipertensi), penyakit kencing manis (diabetes melitus), menurunkan kolesterol, obat bisul, kanker usus dan mencegah stroke. (Alves dkk, 2003)

Pengaturan kerapatan tanaman atau jarak tanam pada dasarnya bertujuan memberikan kemungkinan tanaman untuk tumbuh dengan baik tanpa mengalami persaingan dalam hal pengambilan air, unsur hara, cahaya matahari, dan memudahkan pemeliharaan tanaman. Penggunaan jarak tanam yang kurang tepat dapat merangsang pertumbuhan gulma, sehingga dapat menurunkan hasil. Secara umum hasil tanaman per satuan luas tertinggi diperoleh pada kerapatan tanaman tinggi, akan tetapi bobot masing-masing umbi secara individu menurun karena terjadinya persaingan antar tanaman (Sumarni dan Hidayat, 2005).

Selain pengaturan jarak tanam, penggunaan pupuk dilakukan untuk meningkatkan hasil produksi tanaman bawang dayak baik itu secara kualitas dan kuantitas adalah dengan cara pemberian pupuk organik cair. Pemberian pupuk cair organik diharapkan mampu mengurangi dampak penggunaan pupuk kimia dan mampu memenuhi kebutuhan hara mikro yang dibutuhkan tanaman bawang dayak.

Pupuk organik cair DI Grow adalah pupuk organik generasi mutakhir yang dikenal dunia pertanian. Bahan bakunya berasal dari rumput laut coklat yang dikenal sebagai Acadian Seaweed. Pengolahan yang dilakukan secara ekstraksi menggunakan teknologi NaNo, membuat produk ini menjadi sangat diminati dan digunakan secara luas dihampir negara-negara yang bergerak dibidang produksi pangan dan hortikultura (Darmawati J.S, Nursamsi, Abdul Rasid Siregar, 2014).

Tujuan Penelitian ini adalah sebagai berikut: Untuk mengetahui pengaruh interaksi dan tunggal jarak tanam dan Pupuk Organik Cair DI Grow terhadap pertumbuhan dan hasil tanaman bawang dayak.

\section{METODOLOGI PENELITIAN}

Penelitian telah dilaksanakan di Kebun Percobaan Fakultas Pertanian Universitas Islam Riau, Jalan Kaharuddin Nasution Km 11, Kelurahan Air Dingin, Kecamatan Bukit Raya, Marpoyan, Kota Pekanbaru, Penelitian ini dilaksanakan selama 7 bulan yang dimulai dari bulan April -November 2018 .

Bahan yang digunakan dalam penelitian ini adalah bawang dayak, Pupuk Organik Cair DI Grow, Dithane-45, Furadan 3 GR dan insektisida Decis. Alat-alat yang digunakan dalam penelitian ini adalah cangkul, garu, meteran, pisau kater, ember, handsprayer, gergaji, gelas ukur, timbangan analitik, kuas, gunting, parang, masker, kamera dan alat-alat tulis lainnya.

Rancangan Percobaan ini menggunakan Rancang Acak Lengkap Faktorial yang terdiri dari 2 faktor. Faktor pertama yaitu Pengaruh Jarak Tanam (J) yang terdiri dari 4 taraf dan faktor kedua yaitu Pupuk Organik Cair DI Grow (D) terdiri dari 4 taraf percobaan dan 16 kombinasi perlakuan. Adapun kombinasi perlakuannya jarak tanam (J) dan Dosis POC 
Di Grow (D) terdiri dari : J1 = Jarak Tanam $20 \times 20 \mathrm{~cm}$ (30 tanaman), J2 = Jarak Tanam 20 x $25 \mathrm{~cm}$ (24 tanaman), J3 = Jarak Tanam $20 \mathrm{x}$ $30 \mathrm{~cm}$ (20 tanaman), J4 = Jarak Tanam $25 \times 30$ cm (16 tanaman). Sedangkan Dosis POC Di Grow (D) yaitu : D0 = Tanpa POC DI Grow, D1 = POC DI Grow $3 \mathrm{ml} / \mathrm{l}$ air, D2 = POC DI Grow $6 \mathrm{ml} / \mathrm{l}$ air, D3 = POC DI Grow $9 \mathrm{ml} / \mathrm{l}$ air.

Pelaksanaan Penelitian yang dilakukan adalah Persiapan Lahan, Pembuatan plot, Pemasangan Label, Persiapan bahan tanaman/umbi, Penanaman, Pemberian perlakuan (Jarak tanam dan Dosis D.I Grow), Pemeliharaan (Penyiraman, Penyiangan, Pengendalian hama dan penyakit). Parameter yang diamati adalah laju pertumbuhan relatif, laju asimilasi bersih, jumlah umbi per rumpun, berat umbi basah per rumpun, berat umbi kering angin per rumpun.

\section{HASIL DAN PEMBAHASAN}

\section{A. Laju Asimilasi Bersih (LAB)}

Hasil pengamatan laju asimilasi bersih tanaman bawang dayak pada umur 14-21 dan 21-28 HST setelah dilakukan analisis ragam menunjukkan bahwa secara interaksi perlakuan berbagai jarak tanam dan D.I.Grow tidak berpengaruh nyata, namun secara utama jarak tanam dan D.I.Grow berpengaruh nyata. Rerata laju asimilasi bersih tanaman bawang dayak setelah diuji lanjut BNJ pada taraf $5 \%$ dapat dilihat pada Tabel 1.

Tabel 1. Rerata laju asimilasi bersih tanaman bawang dayak perlakuan berbagai jarak tanam dan D.I.Grow (g/cm²/hari).

\begin{tabular}{|c|c|c|c|c|c|c|}
\hline \multirow{2}{*}{ HST } & \multirow{2}{*}{$\begin{array}{l}\text { Jarak Tanam } \\
\quad(\mathrm{cm})\end{array}$} & \multicolumn{4}{|c|}{ Pupuk Di Grow (ml/l air) } & \multirow{2}{*}{ Rerata } \\
\hline & & D0 (0) & D1 (3) & D2 (6) & D3 (9) & \\
\hline \multirow{6}{*}{$14-21$} & $\mathrm{~J} 1(20 \mathrm{x} 20)$ & 0,00029 & 0,00036 & 0,00041 & 0,00049 & $0,00039 \mathrm{c}$ \\
\hline & $\mathrm{J} 2(20 \mathrm{x} 25)$ & 0,00033 & 0,00040 & 0,00046 & 0,00053 & $0,00043 \mathrm{bc}$ \\
\hline & $\mathrm{J} 3(20$ x 30$)$ & 0,00036 & 0,00046 & 0,00058 & 0,00059 & $0,00050 \mathrm{ab}$ \\
\hline & $\mathrm{J} 4(25$ x 30$)$ & 0,00040 & 0,00064 & 0,00068 & 0,00068 & \multirow[t]{2}{*}{$0,00060 \mathrm{a}$} \\
\hline & \multirow[t]{2}{*}{ Rerata } & $0,00034 \mathrm{c}$ & $0,00047 \mathrm{~b}$ & $0,00053 \mathrm{ab}$ & $0,00057 \mathrm{a}$ & \\
\hline & & \multicolumn{2}{|c|}{$\mathrm{KK}=19,57 \%$} & \multicolumn{2}{|c|}{ BNJ J dan $\mathrm{D}=0,00010$} & \\
\hline \multirow{6}{*}{$21-28$} & $\mathrm{~J} 1(20 \mathrm{x} 20)$ & 0,00054 & 0,00062 & 0,00072 & 0,00075 & $0,00066 \mathrm{~b}$ \\
\hline & $\mathrm{J} 2(20 \times 25)$ & 0,00059 & 0,00073 & 0,00080 & 0,00080 & $0,00073 \mathrm{~b}$ \\
\hline & $\mathrm{J} 3(20$ x 30$)$ & 0,00064 & 0,00080 & 0,00089 & 0,00092 & $0,00081 \mathrm{a}$ \\
\hline & $\mathrm{J} 4(25$ x 30$)$ & 0,00065 & 0,00091 & 0,00093 & 0,00095 & $0,00086 \mathrm{a}$ \\
\hline & \multirow[t]{2}{*}{ Rerata } & $0,00061 \mathrm{c}$ & $0,00077 \mathrm{~b}$ & $0,00084 \mathrm{ab}$ & $0,00086 \mathrm{a}$ & \\
\hline & & \multicolumn{2}{|c|}{$\mathrm{KK}=8,62 \%$} & \multicolumn{2}{|c|}{ BNJ J dan D $=0,000073$} & \\
\hline
\end{tabular}

Angka-angka pada baris dan kolom yang diikuti huruf kecil yang sama menunjukan tidak berbeda nyata menurut uji lanjut BNJ pada taraf $5 \%$.

Data pada tabel 1 menunjukkan bahwa pengaruh utama berbagai jarak tanam berpengaruh nyata terhadap laju asimilasi bersih tanaman bawang dayak pada umur 14$21 \mathrm{HST}$, dimana laju asimilasi bersih tertinggi terdapat pada perlakuan jarak tanam $25 \times 30 \mathrm{~cm}$ (J4) yaitu $0,00060 \mathrm{~g} / \mathrm{cm}^{2} /$ hari, tidak berbeda nyata dengan jarak tanam $20 \times 30 \mathrm{~cm}(\mathrm{~J} 3)$ yaitu $0,00050 \mathrm{~g} / \mathrm{cm}^{2} /$ hari, namun berbeda nyata perlakuan jarak tanam 20x25 cm (J2) dan jarak tanam 20x20 cm (J1). Laju asimilasi bersih tanaman bawang dayak terendah terdapat pada perlakuan jarak tanam 20x20 (J1) yaitu $0,00039 \mathrm{~g} / \mathrm{cm}^{2} /$ hari.

Pada umur 21-28 HST, laju asimilasi bersih tanaman bawang dayak tertinggi terdapat pada pada perlakuan jarak tanam $25 \times 30 \mathrm{~cm}(\mathrm{~J} 4)$ yaitu $0,00086 \mathrm{~g} / \mathrm{cm}^{2} /$ hari, tidak berbeda nyata dengan perlakuan jarak tanam $20 \times 30 \mathrm{~cm}(\mathrm{~J} 3)$ yaitu $0,00081 \mathrm{~g} / \mathrm{cm}^{2} /$ hari namun berbeda nyata perlakuan jarak tanam $20 \times 25 \mathrm{~cm}$ (J2) dan jarak tanam 20x20 cm (J1). Laju asimilasi bersih tanaman bawang dayak 
terendah terdapat pada perlakuan jarak tanam 20x20 (J1) yaitu $0,00066 \mathrm{~g} / \mathrm{cm}^{2} /$ hari.

Laju asimilasi bersih merupakan cerminan dari kemampuan tanaman untuk menghasilkan fotosintat yang nantinya akan teralokasi keseluruh bagian tanaman. Laju asimilasi bersih berasosiasi dengan luas daun dan bahan kering yang dihasilkan dari periode tertentu. Pada tabel 1 terlihat ada perbedaan laju asimilasi bersih antara perlakuan J1 dan $\mathrm{J} 4$, pada perlakuan dengan jarak tanam yang lebih rapat (J1) laju asimilasi besih tanaman bawang dayak relatif lebih rendah dari pada laju asimilasi bersih tanaman yang memiliki jarak tanam lebih jarang (J4) hal ini diduga karena kurangnya kemampuan daun tanaman menyerap cahaya matahari karena populasi tanaman yang terlalu rapat. Sehingga kemapuan daun untuk melakukan fotosisntesis berkurang. Sedikitnya hasil fotosintesis yang dihasilkan tentunya akan menghambat pertumbuhan tanaman itu sendiri, karena hasil fotosistesis merupakan bahan baku pembesaran dan pembelahan sel. Hal ini sesuai dengan pendapat Rosmawaty, dkk (2018) yang mengatakan fotosintat yang dihasilkan dari proses fotosintesis akan digunakan untuk membangun jaringan dan sistem organ pada tanaman.

D.I.Grow memberikan hasil yang lebih baik dari tanpa yang diberikan D.I.Grow, namun demikian pengaruhnya terlihat pada masing-masing taraf perlakuan. Dimana laju asimilasi bersih tanaman bawang dayak tertinggi pada umur 14-21 HST terdapat pada pemberian D.I.Grow $9 \mathrm{ml} / \mathrm{l}$ (D3) yaitu 0,00057 $\mathrm{g} / \mathrm{cm}^{2} /$ hari, tidak berbeda nyata dengan pemberian D.I.Grow $6 \mathrm{ml} / \mathrm{l}$ (D2) yaitu 0,00053 $\mathrm{g} / \mathrm{cm}^{2} /$ hari, namun berbeda nyata dengan pemberian D.I.Grow $3 \mathrm{ml} / \mathrm{l}$ (D1) dan tanpa pemberian D.I.Grow (D0). Sedangkan laju asimilasi bersih terendah terdapat pada perlakuan kontrol (D0) yaitu 0,00034 $\mathrm{g} / \mathrm{cm}^{2} / \mathrm{hari}$.

Pada umur 21-28 HST, laju asimilasi bersih tanaman bawang dayak tertinggi terdapat pada pemberian D.I.Grow $9 \mathrm{ml} / \mathrm{l}$ (D3) yaitu $0,00086 \mathrm{~g} / \mathrm{cm}^{2} / \mathrm{hari}$, tidak berbeda nyata dengan pemberian D.I.Grow $6 \mathrm{ml} / \mathrm{l}$ (D2) yaitu $0,00084 \mathrm{~g} / \mathrm{cm}^{2} /$ hari dan pemberian D.I.Grow 3 $\mathrm{ml} / \mathrm{l}$ (D1) yaitu $0,064 \mathrm{~g} / \mathrm{cm}^{2} / \mathrm{hari}$, namun berbeda nyata dengan pemberian D.I.Grow 3 $\mathrm{ml} / \mathrm{l}$ (D1) dan tanpa pemberian D.I.Grow (D0). Sedangkan laju asimilasi bersih terendah terdapat pada perlakuan kontrol (D0) yaitu $0,00061 \mathrm{~g} / \mathrm{cm}^{2} /$ hari.

Tinggi hasil laju asimilasi bersih tanaman bawang dayak yang mendapat perlakuan Pupuk D.I.Grow $9 \mathrm{ml} / \mathrm{l}$ disuga karena pada perlakuan tersebut kebutuhan unsur hara yang dibutuhkan taman untuk menunjang proses fisiologisnya terpenuhi, selain itu bahan organik yang terkandung dalam pupuk DI Grow juga dapat berfungsi sebagai bahan pembenah tanah (soil conditioner), perbaikan sifat fisik tanah agar tanah menjadi gembur kembali secara bertahap, sehingga pertumbuhan dan perkembangan tanaman menjadi lebih baik. Kekurangan bahan organik di dalam tanah dapat menghambat pertumbuhan generatif tanaman karena sebagian unsur hara digunakan untuk pertumbuhan vegetatif. Menurut Rukmana (2002), kekahatan unsur hara akan menyebabkan penghambatan pertumbuhan generatif tanaman karena adanya upaya pemaksimalan penggunaan hara dan asimilat untuk memacu pertumbuhan vegetatif tanaman

\section{B. Jumlah Umbi Per Rumpun}

Hasil pengamatan terhadap jumlah umbi per rumpun tanaman bawang dayak dengan perlakuan jarak tanam dan pupuk DI Grow setelah dilakukan analisis sidik ragam menunjukkan bahwa jarak tanam dan pupuk DI Grow secara interaksi tidak berpengaruh nyata, namun secara utama jarak tanam dan pupuk DI Grow berpengaruh nyata. Rata-rata jumlah umbi per rumpun tanaman bawang dayak dapat dilihat pada tabel 2 .

Pada tebel 2 terlihat bahwa perlakuan berbagai jarak tanam secara utama memberikan pengaruh yang nyata dimana jumlah umbi terbanyak terdapat pada perlakuan J4 (jarak tanam 25x30) adalah 18,42 buah. Perlakuan J4, J3 dan J2 namun berbeda nyata dengan $\mathrm{J} 1$.

Banyaknya jumlah umbi pada perlakuan jarak tanam $25 \times 30 \mathrm{~cm}$ diduga karena terpenuhinya kebutuhan unsur hara, air dan cahaya untuk pertumbuhan, terpenuhi Terutama unsur N, P dan K. Seperti yang dikatakan oleh Rosmawaty, dkk (2019) Unsur $\mathrm{N}$ diserap dan dimanfaatkan oleh tanaman, terutama pada pertumbuhan vegetatif, diantaranya $\mathrm{N}$ digunakan untuk pembentukan protein, pembentukan klorofil dan senyawasenyawa lainya sehingga pertumbuhan tanaman menjadi lebih baik, Fospor (P) 
bermanfaat untuk membantu pembentukan protein dan mineral yang sangat penting bagi tanaman, unsur hara $(\mathrm{P})$ juga bertugas mengedarkan energi keseluruh bagian tanaman, merangsang pertumbuhan akar. Sedangkan unsur hara potasium $(\mathrm{K})$ bermanfaat untuk membentuk protein, karbohidrat dan gula. Membantu pengangkutan gula dari daun ke buah, memperkuat jaringan tanaman serta meningkatkan daya tahan penyakit.

Tabel 2. Rerata umlah umbi per rumpun tanaman bawang dayak dengan perlakuan jarak tanam dan pupuk DI Grow.

\begin{tabular}{|c|c|c|c|c|c|}
\hline \multirow{2}{*}{ Jarak Tanam $(\mathrm{cm})$} & \multicolumn{4}{|c|}{ Pupuk Di Grow (ml/l air) } & \multirow{2}{*}{ Rerata } \\
\hline & D0 (0) & D1 (3) & D2 (6) & D3 (9) & \\
\hline $\mathrm{J} 1(20 \mathrm{x} 20)$ & 14,67 & 15,33 & 16,33 & 17,33 & $15,92 \mathrm{~b}$ \\
\hline $\mathrm{J} 2(20 \times 25)$ & 15,67 & 16,33 & 17,00 & 18,67 & $16,92 \mathrm{ab}$ \\
\hline $\mathrm{J} 3(20 \times 30)$ & 16,00 & 17,67 & 18,00 & 19,00 & $17,67 \mathrm{ab}$ \\
\hline $\mathrm{J} 4(25 \mathrm{x} 30)$ & 17,67 & 18,00 & 18,67 & 19,33 & $18,42 \mathrm{a}$ \\
\hline Rerata & $16,00 \mathrm{~b}$ & $16,83 \mathrm{ab}$ & $17,50 \mathrm{ab}$ & $18,58 \mathrm{a}$ & \\
\hline
\end{tabular}

Angka-angka pada baris dan kolom yang diikuti huruf kecil yang sama menunjukan tidak berbeda nyata menurut uji lanjut BNJ pada taraf $5 \%$.

Hal ini sesuai dengan pendapat Hardjowigeno (2003) bahwa nitrogen diperlukan tanaman untuk memproduksi protein dan bahan-bahan penting lainnya dalam proses pembentukan sel-sel serta berperan dalam pembentukan klorofil. Selanjtnya Muliyadi (2007) juga menjelaskan bahwa unsur fospor (P) berguna untuk membentuk akar, memperkuat batang tanaman, serta meningkatkan hasil. Selain itu, unsur kalium (K) berguna untuk memperkuat tubuh tanaman agar daun, bunga dan buah tidak mudah gugur, termasuk umbi. Suryatna (2007), menambahkan bahwa tanaman tidak akan mencapai pertumbuhan dan hasil yang maksimal tanpa unsur Nitrogen, Fosfor dan Kalium.

Selain perlakuan jarak tanam Data pada tabel 2 juga menunjukkan bahwa pemberian pupuk DI Grow juga berpengaruh nyata terhadap jumlah umbi per rumpun tanaman bawang dayak. Dimana perlakuan D.I.Grow 9 $\mathrm{ml} / \mathrm{l}$ (D3) dengan rata-rata jumlah umbi per rumpun tanaman bawang dayak 18,58 buah merupakan perlakuan terbaik. Perlakuan D3 tidak berbeda nyata dengan perlakuan perlakuan D2, D1, tetapi bebeda dengan pelakuan D0. Pemberian pupuk D.I.Grow 9 $\mathrm{ml} / \mathrm{l}$ (D3)menghasilkan jumlah umbi per rumpun lebih banyak dibandingkan dengan tanpa pemberian pupuk D.I.Grow, hal ini diduga karena terpenuhinya kebutuhan unsur hara untuk pertumbuhan dan produksi tanaman bawang dayak. Selain itu, Rosmarkam dan Yuwono (2011) menyampaikan bahwa unsur hara yang tersedia dalam media tanam yang mampu diserap tanaman dengan jumlah yang tepat dan seimbang mampu meningkatkan produksi tanaman.

\section{Berat Umbi Basah Perrumpun}

Hasil pengamatan berat basah per rumpun tanaman bawang dayak dengan perlakuan jarak tanam dan pupuk DI Grow setelah dilakukan analisis ragam, perlakuan jarak tanam dan pupuk DI Grow secara interaksi tidak berpengaruh nyata, namun secara utama jarak tanam dan pupuk DI Grow memberikan pengaruh. Rata-rata berat basah perrumpun tanaman bawang dayak dapat dilihat pada Tabel 3.

Pada tabel 3 terlihat bahwa perlakuan berbagai jarak tanam secara utama memberikan pengaruh yang nyata terhadap berat umbi basah per rumpun tanaman bawang dayak, dimana berat umbi basah tertinggi perlakuan J4 adalah 244,91 g. Perlakuan ini berbeda nyata dengan $\mathrm{J} 3, \mathrm{~J} 2$ dan $\mathrm{J} 1$.

Berat umbi per rumpun pada perlakuan jarak tanam $25 \times 30 \mathrm{~cm}$ yaitu $244,91 \mathrm{~g} /$ rumpun atau setara dengan 32,65 ton/ha jika dibandingkan dengan hasil pada perlakuan jarak tanam 20x20 cm (J1) yaitu 138,10 g/rumpun atau setara dengan 34,5 ton/ha, walaupun populsi per hektar perlakuan J4 dan 
J1 berbeda sekitar 120.000 tanamam namun produksi perhektar kedua perlakuan tersebut tidak berbeda jauh. Hal ini karena pertumbuhan tanaman pada perlakuan J4 lebih baik dari pada pertumbuhan tanaman pada perlakuan J1 kurangnya persaingan unsur hara, air dan cahaya yang dibutuhkan oleh tanaman untuk menunjang proses fisiologisnya. Sehingga meningkatkan hasil fotosistesis yang kemudian akan di gunakan sebagai bahan baku pembesaran dan pembelahan sel. Hal ini sesuai dengan pendapat Rosmawaty, dkk (2018) yang mengatakan fotosintat yang dihasilkan dari proses fotosintesis akan digunakan untuk membangun jaringan dan sistem organ pada tanaman. Sehingga meningkatnya hasil fotosintesis yang disebabkan oleh terpenuhinya unsurhara, air dan cahaya akan meningkatkan produksi tanaman itu sendiri.

Tabel 3. Rerata berat umbi basah perrumpun bawang dayak dengan perlakuan jarak tanam dan pupuk DI Grow (g).

\begin{tabular}{|c|c|c|c|c|c|}
\hline \multirow{2}{*}{ Jarak Tanam $(\mathrm{cm})$} & \multicolumn{4}{|c|}{ Pupuk Di Grow (ml/1 air) } & \multirow{2}{*}{ Rerata } \\
\hline & D0 (0) & D1 (3) & D2 (6) & D3 (9) & \\
\hline $\mathrm{J} 1(20 \mathrm{x} 20)$ & 123,17 & 134,83 & 143,83 & 150,57 & $138,10 \mathrm{~d}$ \\
\hline $\mathrm{J} 2(20 \times 25)$ & 161,43 & 173,10 & 181,00 & 188,30 & $175,96 \mathrm{c}$ \\
\hline $\mathrm{J} 3(20 \times 30)$ & 193,57 & 199,50 & 212,70 & 224,60 & $207,59 \mathrm{~b}$ \\
\hline $\mathrm{J} 4(25 \mathrm{x} 30)$ & 225,83 & 239,30 & 259,00 & 255,50 & $244,91 \mathrm{a}$ \\
\hline Rerata & $176,00 \mathrm{c}$ & $186,68 \mathrm{~b}$ & $199,13 \mathrm{a}$ & $204,74 \mathrm{a}$ & \\
\hline
\end{tabular}

Angka-angka pada baris dan kolom yang diikuti huruf kecil yang sama menunjukan tidak berbeda nyata menurut uji lanjut BNJ pada taraf $5 \%$.

Selain perlakuan jarak tanam Data pada tabel 3 juga menunjukkan bahwa pemberian pupuk DI Grow juga berpengaruh nyata terhadap berat umbi basah per rumpun tanaman bawang dayak. Dimana perlakuan D.I.Grow $9 \mathrm{ml} / \mathrm{l}$ (D3) dengan rata-rata berat umbi basah per rumpun tanaman bawang dayak 204,74 g merupakan perlakuan tertinggi. Perlakuan D3,D2.tetapi bebeda dengan pelakuan D1 dan D0. Hal itu karena pupuk D.I Grow merupakan pupuk organik yang mengandung unsur hara esensial makro dan mikro yang dibutuhkan oleh tanaman, seperti yang dikatakan oleh Parman (2007) yang mengatakan D.I Grow mengandung unsur hara lengkap baik makro (N, P, K, Ca, Mg, S) dan mikro ( $\mathrm{Fe}, \mathrm{Zn}, \mathrm{Cu}, \mathrm{Mo}, \mathrm{Mn}, \mathrm{B}, \mathrm{Cl}$ ), asam amino, zat perangsang tumbuh (Auksin, Sitokinin, Giberellin), asam humik dan asam alginate. Penambahan unsur hara berupa pupuk organik adalah sangat penting untuk pertumbuhan tanaman. Tanaman bawang mampu menghasilkan berat umbi yang tinggi, disebabkan karena karbohidrat, protein, lemak dan asam-asam organik lainnya yang dihasilkan dari kegiatan fotosintesis disimpan dalam umbi lapis (Mardani, dkk. 2019).

\section{Berat Umbi Kering Perrumpun}

Hasil pengamatan berat kering perrumpun tanaman bawang dayak dengan perlakuan jarak tanam dan pupuk DI Grow setelah dilakukan analisis ragam perlakuan jarak tanam dan pupuk DI Grow secara interaksi tidak berpengaruh nyata terhadap berat kering perrumpun tanaman bawang dayak, namun pengaruh utama perlakuan jarak tanam dan pupuk DI Grow memberikan pengaruh yang nyata terhadap berat kering. Rata-rata berat kering perrumpun tanaman bawang dayak dapat dilihat pada Tabel 4 .

Berat kering tanaman mencerminkan indikasi keberhasilan pertumbuhan tanaman, karena merupakan petunjuk adanya hasil fotosintesis bersih yang dapat diendapkan setelah kadar airnya dikeringkan. Berat umbi per rumpun tanaman bawang dayak pada perlakuan J4 sebanyak 185,70 g/rumpun, jika dikonfersikan ke hektar sama dengan 24,7 ton/ha. Hasil ini jauh lebih tinggi dari produksi bawang dayak per hektar menurut deskripsi yang hanya 7 ton. Tingginya produksi bawang dayak pada perlakuan jarak tanam J4 karena pada disuga perlakuan tersebut mampu meningkatkan produksi tanaman bawang dayak, karena jumla populasi tanaman yang tidak terlalu rapat akan meningkatkan 
kemampuan tanaman dalam menyerap unsur hara, air dan cahaya yang dibutuhkan oleh tanaman untuk proses fisiologisnya.

Tabel 4. Rerata berat kering perrumpun bawang dayak dengan perlakuan jarak tanam dan pupuk DI Grow (g).

\begin{tabular}{|c|c|c|c|c|c|}
\hline \multirow{2}{*}{ Jarak Tanam $(\mathrm{cm})$} & \multicolumn{4}{|c|}{ Pupuk Di Grow (ml/l air) } & \multirow{2}{*}{ Rerata } \\
\hline & D0 (0) & D1 (3) & D2 (6) & D3 (9) & \\
\hline $\mathrm{J} 1(20$ x 20) & 90,04 & 99,13 & 105,74 & 110,34 & $101,31 \mathrm{~d}$ \\
\hline $\mathrm{J} 2(20$ x 25$)$ & 120,41 & 129,83 & 136,02 & 142,83 & $132,27 \mathrm{c}$ \\
\hline $\mathrm{J} 3(20$ x 30$)$ & 146,51 & 152,77 & 164,00 & 173,44 & $159,18 \mathrm{~b}$ \\
\hline $\mathrm{J} 4(25 \mathrm{x} 30)$ & 172,86 & 184,86 & 189,46 & 195,63 & $185,70 \mathrm{a}$ \\
\hline \multirow[t]{2}{*}{ Rerata } & $132,45 \mathrm{c}$ & $141,64 \mathrm{~b}$ & $148,80 \mathrm{a}$ & $155,56 \mathrm{a}$ & \\
\hline & \multicolumn{2}{|c|}{$\mathrm{KK}=4,36 \%$} & dan D & & \\
\hline
\end{tabular}

Angka-angka pada baris dan kolom yang diikuti huruf kecil yang sama menunjukan tidak berbeda nyata menurut uji lanjut BNJ pada taraf $5 \%$.

Selain perlakuan jarak tanam Data pada tabel 4 juga menunjukkan bahwa pemberian pupuk DI Grow juga berpengaruh nyata terhadap berat umbi kering per rumpun tanaman bawang dayak. Dimana perlakuan D.I.Grow $9 \mathrm{ml} / \mathrm{l}$ (D3) dengan rata-rata berat umbi kering per rumpun tanaman bawang dayak 155,56 g merupakan perlakuan terbaik. Perlakuan D3 tidak berbeda nyata dengan perlakuan perlakuan D2, D1 dan D0 .

Berat kering umbi per rumpun erat hubungannya kandungan unsur hara, karena berat kering mencerminkan indikasi keberhasilan pertumbuhan tanaman. Berat kering merupakan petunjuk adanya hasil fotosintesis bersih yang dapat diendapkan setelah kadar airnya dikeringkan. Sesuai dengan pendapat Saragih (2013) yang mengatakan bahwa pupuk berperan dalam proses fotosintesis dimana pupuk sebagai salah satu penyuplai unsur hara yang dibutuhkan tanaman dalam proses metabolisme tanaman.

\section{KESIMPULAN}

Hasil penelitian yang telah dilaksanakan dapat diambil kesimpulan bahwa:

1. Interaksi pemberian perlakuan jarak tanam dan pupuk DI Grow tidak berpengaruh terhadap laju asimilasi bersih, jumlah umbi, berat basah unbi dan berat kering umbi per rumpun.

2. Pengaruh utama jarak tanam nyata terhadap laju asimilasi bersih, jumlah umbi per rumpun, berat umbi basah per rumpun, berat umbi kering angin per rumpun. Perlakuan terbaik adalah jarak tanam $25 \times 30 \mathrm{~cm}$.

3. Pengaruh utama pupuk DI Grow nyata terhadap, laju asimilasi bersih, jumlah umbi per rumpun, berat umbi basah per rumpun, berat umbi kering angin per rumpun. Perlakuan terbaik adalah dosis pupuk DI Grow $9 \mathrm{ml} / \mathrm{l}$ air.

Dari hasil penelitian, penulis menyarankan untuk melakukan penelitian lanjutan dengan perlakuan jarak tanam $25 \mathrm{x}$ 30 dan dosis POC DI Grow diatas $9 \mathrm{ml} / \mathrm{l}$ air karena pada dosis tersebut tanaman bawang dayak sudah mampu berproduksi secaraoptimal.

\section{DAFTAR PUSTAKA}

Alves TMA. Helmut. K dan Carlos LZ. 2003. Eleutherinone a Novel Fungitoxiic Napthoquinone from Eleutherine Bulbosa (Iridiceae). Mem. Inst. OsvaldoCruz. Rio de Janeiro. 98 (5) : 709-712.

Anggraini, L. T., Haryati dan T. Irmansyah. 2014. Pengaruh Jarak Tanam dan Pemberian Kompos Jerami Padi terhadap Pertumbuhan dan Produksi Bawang Sabrang (Eleutherine americana Merr.). Jurnal Online Agroteknologi Fakultas Pertanian USU Medan. 2 (3):974-981.

Darmawati J.S, Nursamsi, Abdul Rasid Siregar. 2014 . Pengaruh pemberian limbah padat (sludge) kelapa sawit dan pupuk organik cair terhadap 
pertumbuhan dan produksi tanaman jagung manis (Zea Mays Saccharata.) Program Studi Agroekoteknologi Fakultas Pertanian UMSU. 19 (1): 5967.

Febrinda, A.E., Made,A., Tutik,W., dan Nancy, D.Y., 2013. "Kapasitas Antioksidan dan Inhibitor Alfa Glukosidase Ekstrak Umbi Bawang Dayak". J.Teknol. Dan Industri Pangan. 24 (2): 161

Galingging, R.Y. 2007. Bawang Dayak (Eleutherine palmifolia) Sebagai Tanaman Obat Multifungsi. BPTP Kalimantan Tengah. Kalimantan Tengah.

Hadisuwito, S. 2012. Membuat Pupuk Organik Cair. Agromedia Pustaka. Jakarta.

Hardjowigeno. 2003. Ilmu Tanah. Akademia Pressindo. Bogor

Indrawati, N., Razimin. 2013. Bawang Dayak $\mathrm{Si}$ Umbi Ajaib Penakluk Aneka Penyakit. Penerbit : PT agromedia pustaka. Jakarta.

Kuntorini, E.M., Maria, D.A., dan L.Hartanto, N., 2010."Struktur Anatomi dan Aktivitas Antioksidan Bulbus Bawang Dayak (Eleutherine americana Merr.) dari Daerah Kalimantan Selatan”. Berk. Penel. Hayati. Vol.16. Hal: 1

Lakitan, B. 2008. Dasar-Dasar Fisiologi Tumbuhan. Raja Grafindo Persada. Jakarta.

Mardani. 2019. Pengaruh Jarak Tanam dan Pemberian Pupuk Organik Cair DI Grow Terhadap Pertumbuhan dan Hasil Tanaman Bawang Dayak (Eleutherine americana merr). Skripsi Fakultas Pertanian Universitas Islam Riau. Pekanbaru

Murbandono, H.S.2005. Membuat kompos. Penebar Swadaya. Jakarta.

Mursito, D dan Kawiji. 2001. Pengaruh Kerapatan Tanam dan Kedalaman Olah Tanah Terhadap Hasil Umbi Lobak (Raphanus sativus L.). Universitas Sebelas Maret. Surakarta.

Parman, S. 2007. Pengaruh Pemberian Pupuk Organik Cair terhadap Pertumbuhan dan Produksi Kentang (Solanum tuberosum L.). Buletin Anatomi.

Pranata dan S, Ayub. 2010. Meningkatkan Hasil Panen dengan pupuk Organik.PT Agromedia Pustaka. Jakarta. Plantamor, 2012.Informasi Spesies kundur.http://www.plantamor.com/index .ph.Diaksees tanggal 17 Agustus 2018.

Pratiwi, D., Sri,W., dan Isnindar., 2013. "Uji Aktivitas Antioksidan Daun Bawang Mekah (Eleutherine Americana Merr.) Dengan Metode DPPH (2,2-Difenil1pikrilhidrazil)". Traditional Medicine Journal . 18(1) : 9-14

Putra, R. Y. 2012. Respons pertumbuhan dan hasil bawang sabrang (Eleuthrine americana merr.) pada berbagai jarak tanam dan berbagai tingkat pemotongan umbi. J. Agroekoteknologi, Vol 1:159171.

Rosmarkam, A dan N. W. Yuwono,. 2011. Ilmu kesuburan tanah. Kanisius. Yogyakarta.

Rosmawaty, T. H, B. Jumin. Mardaleni, Charles, S. 2018. Produksi Dan Kandungan Flavonoid umbi Tanaman Bawang Dayak (Eleutherine Palmifolia) dengan pemberian NPK16.16.16 pada Berbagai Umur Panen. L aporan Penelitian LPPM Universitas Islam Riau. Pekanbaru

Rosmawaty, T. Mardaleni, A. R. Musa. 2017. Aplikasi Pupuk NPK Organik dan D.I.Grow Terhadap Pertumbuhan dan Hasil Tanaman Bawang Dayak (Eleutherine americana Merr). Laporan Penelitian LPPM Universitas Islam Riau. Pekanbaru

Saragih, D., Herawati Hamim dan Niar Nurmauli. 2013. Pengaruh waktu dan dosis terhadap pemberian pupuk urea dalam meningkatkan pertumbuhan dan hasil tanaman jagung manis (zea mays. L). Jurnal Agrotek Tropika Jurusan Agroteknologi Fakultas Pertanian Universitas Lampung. Lampung. 1 (1) : 50-54.

Sulastri, E., Cristadeolia, O., dan Yusriadi., 2015. "Formulasi Mikroemulsi Ekstrak Bawang Hutan dan Uji Aktivitas Antioksidan". Jurnal Pharmascience. 2 (2): $2-9$

Sumarni, N. , R. Rosliani, dan Suwandi. 2012. Optimasi Jarak Tanam dan Dosis Pupuk NPK untuk Produksi Bawang Merah dari Benih Umbi Mini di Dataran Tinggi. J. Hort. Vol 22:148-155.

Sumarni, N., dan A. Hidayat. 2005. Budidaya Bawang Merah. Panduan Teknis PTT Bawang Merah No. 3. Balai Penelitian Tanaman Sayuran. Pusat Penelitian dan 
Pengaruh Jarak Tanam dan Pemberian Pupuk Organik Cair DI Grow terhadap Pertumbuhan dan Hasil Tanaman Bawang Dayak (Eleutherine americana merr)

Pengembangan Hortikultura.Badan
Penelitian dan Pengembangan Pertanian.
Bandung. Bandung.
Prat 2007. Kiat Mengatasi Permasalahan Praktis Petunjuk Pemupukan. Redaksi Agromedia Pustaka.

Suryatna. 2007. Kiat Mengatasi Permasalahan Praktis. Petunjuk Pemupukan. Agromedia. Jakarta.

Utami. P. 2013. Uji Aktivitas Antioksidan Umbi Bawang Dayak (Eleutherine palmifolia). Skripsi Fakultas Matematika dan Ilmu Pengetahuan Alam Universitas Islam Bandung. Bandung.

Wardani. R. 2009. Identifikasi Kandungan Senyawa Metabolit Sekunder Ekstrak Kloroform Umbi Bawang Dayak (Eleutherine palmifolia). Makalah Seminar Kimia di Fakultas Keguruan dan Ilmu Pendidikan Universitas Palangkaraya. Hal : 1-10. 24 Mei 2014. 
